\title{
Article \\ Antimicrobial Efficacy of Propolis in Comparison to Chlorhexidine against Enterococcus faecalis: A Systematic Review and Meta-Analysis
}

\author{
Khalid H. Almadi ${ }^{1}$, Muhammad Adeel Ahmed ${ }^{2, *}{ }^{\circledR}$, Tuba Ghazal ${ }^{3}$, Rizwan Jouhar ${ }^{2}{ }^{\circledR}$, Mazen F. Alkahtany ${ }^{1}$, \\ Tariq Abduljabbar ${ }^{4}$ (D) and Fahim Vohra ${ }^{4}$ (D) \\ 1 Department of Restorative Dental Science, Division of Endodontics, College of Dentistry, King Saud \\ University, Riyadh 11545, Saudi Arabia; kalmadi@ksu.edu.sa (K.H.A.); malkahtany@ksu.edu.sa (M.F.A.) \\ 2 Department of Restorative Dentistry and Endodontics, College of Dentistry, King Faisal University, \\ Al-Ahsa 31982, Saudi Arabia; rjouhar@kfu.edu.sa \\ 3 Department of Community Dentistry, Dr. Ishrat-ul-Ebad Khan Institute of Oral Health Science, \\ Dow University of Health Sciences, Karachi 74200, Pakistan; tubaghaxal@gmail.com \\ 4 Department of Prosthetic Dental Science, Research Chair for Biological Research in Dental Health, \\ College of Dentistry, King Saud University, Riyadh 11545, Saudi Arabia; tajabbar@ksu.edu.sa (T.A.); \\ fvohra@ksu.edu.sa (F.V.) \\ * Correspondence: mshakeel@kfu.edu.sa; Tel.: +966-581674914
}

\section{check for}

updates

Citation: Almadi, K.H.; Ahmed, M.A.; Ghazal, T.; Jouhar, R.;

Alkahtany, M.F.; Abduljabbar, T.;

Vohra, F. Antimicrobial Efficacy of

Propolis in Comparison to

Chlorhexidine against Enterococcus faecalis: A Systematic Review and Meta-Analysis. Appl. Sci. 2021, 11, 3469. https://doi.org/10.3390/ app11083469

Academic Editor: Gabi Chaushu

Received: 3 March 2021

Accepted: 5 April 2021

Published: 13 April 2021

Publisher's Note: MDPI stays neutral with regard to jurisdictional claims in published maps and institutional affiliations.

Copyright: (c) 2021 by the authors. Licensee MDPI, Basel, Switzerland. This article is an open access article distributed under the terms and conditions of the Creative Commons Attribution (CC BY) license (https:// creativecommons.org/licenses/by/ $4.0 /)$.

\begin{abstract}
Propolis is proposed to possess antibacterial and anti-inflammatory properties, which can be used in endodontic applications. However, evidence on its efficacy in comparison to chlorhexidine against Enterococcus faecalis (E. faecalis) is controversial. The aim of the current study was to compare the antibacterial efficacy of Propolis and chlorhexidine as an intracanal medicament against $E$. faecalis in extracted human permanent teeth. The focused question was, "Does Propolis show better antibacterial efficacy than Chlorhexidine (CHX) as an intracanal medicament against E. faecalis in extracted human permanent teeth?". Databases including PubMed/Medline, Scopus, EMBASE, ISI-Web of Science were searched from 1990 to August 2020 using different combinations of the following keywords: "Propolis", "Intracanal medicament", “E. faecalis", "Antibacterial activity” and "Chlorhexidine". Ten studies fulfilling inclusion criteria were considered for qualitative analysis, followed by quantitative analysis of eight studies. Heterogeneity was calculated for colony forming units (CFU) of E. Faecalis using the Chi-square test and $\mathrm{I}^{2}$ statistics. Forest plots were computed reporting standard mean difference (SMD) of outcomes and $95 \%$ confidence intervals. The overall mean difference for CFU of E. faecalis showed a statistically significant difference between the antibacterial efficacy of Propolis and CHX $(\mathrm{SMD}=3.20[1.70,4.69] \mathrm{Z}=4.20 ; p<0.001)$. CHX showed superior antibacterial efficacy against E. faecalis compared to Propolis.
\end{abstract}

Keywords: propolis; polyphenolic compound; chlorhexidine; intracanal medicament; E. faecalis; systematic review

\section{Introduction}

One of the most prevalent bacteria isolated from the infected root canal of failed obturation is Enterococcus faecalis [1,2]. Enterococcus faecalis (E. faecalis) is a facultative anaerobic gram-positive bacterium. It is considered as one of the most resistant bacterium that is difficult to eliminate due to its ability to invade dentinal tubules, compete with other bacteria and survive in harsh environments for a considerable long time without nutrition [3].

Intracanal medicament has a pivotal role in the eradication of microorganisms from an infected root canal [4,5]. Chlorhexidine is bis-biguanide and possesses prolong substantivity. It is bacteriostatic in low concentration while bactericidal in high concentration [6]. The efficacy of chlorhexidine against E. faecalis is established by various studies [6-8]. De Lucena 
et al. [7] reported high efficacy of chlorhexidine in contrast to calcium hydroxide against E. faecalis. Similarly, Savitha et al. [8] found significant inhibition of E. faecalis by $2 \%$ chlorhexidine medicament gel in endodontic re-treatment procedure using RT-qPCR.

In recent years, a paradigm shift from synthetic to natural medicament has been noticed. Various researches have focused on natural intracanal medicament that is deleterious to all bacteria and free from the unwanted effect of synthetic medicaments [9]. One of the newly emerging natural intracanal medicaments is Propolis. Propolis is a wax cum resin substance that contains 58 to $78 \%$ polyphenolic compounds prepared by honeybees to protect their honey from contamination of microorganisms [10]. It has an array of antibacterial, antioxidant, and anti-inflammatory properties that render its use for multiple indications in dentistry [11]. Numerous studies have recommended the use of Propolis as an intracanal medicament due to its effectiveness against E. faecalis [11-13]. Awawdeh et al. [13] and Victorino et al. [12] showed that Propolis was more efficient than calcium hydroxide against E. faecalis, while Madhubala et al. [14] reported the efficacy of Propolis as $100 \%$ against $E$. faecalis following a 7 -day application.

In light of existing literature, controversy exists in the efficacy of Propolis and chlorhexidine against $E$. faecalis. It is hypothesized that Propolis exhibits comparable antimicrobial efficacy in comparison to CHX against $E$. faecalis. Therefore, the aim was to perform a systematic review that can evaluate the antibacterial activity of Propolis in comparison to chlorhexidine against $E$. faecalis in extracted human teeth.

\section{Materials and Methods}

\subsection{Protocol Registration}

The study protocol was registered on the PROSPERO International prospective register of systematic reviews with the registration no. CRD42020201052. The PRISMA guideline was followed for reporting this systematic review and meta-analysis.

\subsection{Focused Question}

"Does Propolis show better antibacterial activity than chlorhexidine as an intracanal medicament against $E$. faecalis in extracted human permanent teeth?"

\subsection{Search Strategy}

An extensive literature search was made, including Pubmed/Medline (National Library of Medicine, Bethesda, 74 Maryland), Scopus/EMBASE/ISI Web of Science using different combinations of the following keywords: Propolis; intracanal medicament; E. faecalis; antibacterial activity. All papers published in the last 20 years, from June 2000 to June 2020, were retrieved. The title and abstract of all papers were read and matched with inclusion criteria. All papers fulfilling inclusion criteria were considered relevant (Figure 1). 


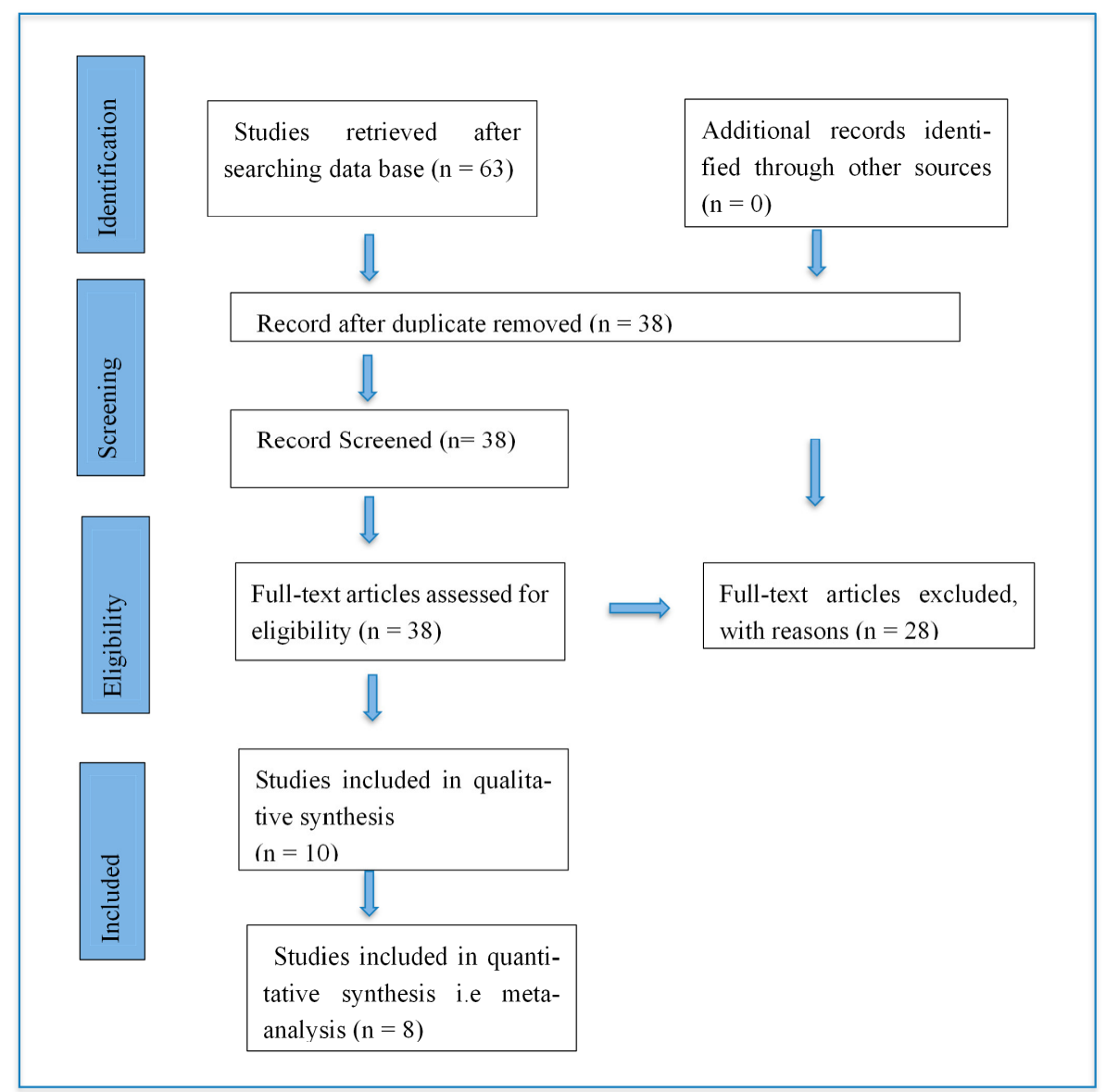

Figure 1. Schematic representation of the PRISMA flowchart for literature search performed in this study.

\subsection{Inclusion Criteria}

Studies performed in extracted human permanent teeth comparing the antibacterial activity of Propolis and chlorhexidine as an intracanal medicament against E. faecalis were included.

\subsection{Exclusion Criteria}

The following studies were excluded, (a) all in vivo studies, (b) studies performed on animal or bovine teeth, (c) studies involving human primary extracted teeth (deciduous teeth), (d) case reports, review articles, commentaries, letter to the editor, unpublished articles, and (e) studies performed on less than 10 samples.

\subsection{Study Selection and Data Extraction}

Studies were selected according to the inclusion criteria by the principal investigator (MAA), then re-checked and confirmed by the second investigator (FV), if there were disagreements between the judgments of these two investigators, then a third investigator's opinion was used to resolve the issue. The principal investigator searched through ClinicalTrials.gov, International Clinical Trials Registry Platform (ICTRP), Dissertation and Theses Global, and conference proceedings at Embase and Scopus for Gray literature. In addition, articles were manually searched, and an assessment of references of the selected articles was undertaken. However, no new studies were found or included based on the inclusion criteria.

The data were extracted from included studies and transferred to a data form containing general information about the studies (Table 1). In Table 2, the total number of samples, 
test group and control group, medicament used, medicament duration, inoculation period, outcome measure, and outcome evaluation method were noted.

Table 1. General characteristics of included studies.

\begin{tabular}{|c|c|c|c|c|c|c|}
\hline $\begin{array}{l}\text { Study } \\
\text { Number }\end{array}$ & Authors & Year & Country & Test Group & Control Group & Outcome \\
\hline \multicolumn{7}{|c|}{ Group 1. CFU count as outcome measure } \\
\hline 1 & $\begin{array}{c}\text { Agrima } \\
\text { Vasudeva et al. }\end{array}$ & 2017 & India & $\begin{array}{c}\text { Propolis, } \\
\text { Chlorhexidine, } \\
\text { Honey gel, } \\
\text { Calcium } \\
\text { hydroxide, } \\
\text { Curcuma longa } \\
\text { gel, Aloe vera } \\
\text { gel, }\end{array}$ & Saline & $\begin{array}{l}\text { 2\% Chlorhexidine gel was } \\
\text { most effective followed by } \\
\text { Propolis and Curcuma longa }\end{array}$ \\
\hline 2 & $\begin{array}{c}\text { Jeison B. } \\
\text { Carbajal Mejía }\end{array}$ & 2014 & Peru & $\begin{array}{c}\text { CHX, Propolis, } \\
\text { CaOH }\end{array}$ & Saline & $\begin{array}{l}\text { There was no significant } \\
\text { difference between CHX and } \\
\text { Propolis reducing E. faecalis }\end{array}$ \\
\hline 3 & $\begin{array}{c}\text { Sonam } \\
\text { Bhandari et al. }\end{array}$ & 2014 & India & $\begin{array}{c}\text { CHX, Propolis, } \\
\text { CaOH }\end{array}$ & Saline & $\begin{array}{l}2 \% \text { chlorhexidine produced } \\
100 \% \text { antimicrobial efficacy as } \\
\text { compared to Propolis }(66.37 \%)\end{array}$ \\
\hline 4 & $\begin{array}{l}\text { Leila Bazvand } \\
\text { et al. }\end{array}$ & 2014 & Iran & $\begin{array}{l}\text { Triantibiotic, } \\
\text { CHX, Propolis, } \\
\text { Aloe vera }\end{array}$ & Saline & $\begin{array}{l}\text { There were no significant } \\
\text { differences between the means } \\
\text { of CFUs for the TAM, CHX, } \\
\text { and Propolis groups }(p>0.05) \text {. } \\
\text { The mean CFU for the Aloe } \\
\text { vera group was significantly } \\
\text { more than those in the three } \\
\text { other experimental groups } \\
(p<0.05) \text {. }\end{array}$ \\
\hline 5 & Maekawa et al. & 2013 & Brazil & $\begin{array}{l}\text { Propolis, } \mathrm{CHX} \text {, } \\
\mathrm{CaOH}, \text { glycolic } \\
\text { ginger extracts }\end{array}$ & Saline & $\begin{array}{l}\text { All ICMs(including Propolis) } \\
\text { were able to eliminate } \\
\text { E. faecalis in the root canals, } \\
\text { except for CH paste, which } \\
\text { did not eliminate completely } \\
\text { E. faecalis. }\end{array}$ \\
\hline 6 & $\begin{array}{c}\text { Guven } \\
\text { Kayaoglu et. al }\end{array}$ & 2011 & Turkey & $\begin{array}{c}2 \% \mathrm{CHX} \\
\text { Propolis, } \mathrm{CaOH}\end{array}$ & $\begin{array}{l}\text { Ethanol/ } \\
\text { Phosphate- } \\
\text { Buffer saline }\end{array}$ & $\begin{array}{c}\text { Propolis samples were not } \\
\text { superior to CHX in terms of } \\
\text { bacterial elimination, although } \\
\text { a significant reduction in the } \\
\text { cultivable numbers of bacteria } \\
\text { was achieved }\end{array}$ \\
\hline 7 & $\begin{array}{l}\text { D. } \\
\text { Kandaswamy } \\
\text { et al. }\end{array}$ & 2010 & India & $\begin{array}{c}\text { Propolis, } \\
\text { MCJ(morinda } \\
\text { citrifolia juice), } \\
\text { CaOH, } \\
\text { Povidone } \\
\text { Iodine, } \mathrm{CHX} \text {. }\end{array}$ & Saline & $\begin{array}{l}\text { Two percent chlorhexidine } \\
\text { demonstrated significant } \\
\text { inhibition against E. faecalis } \\
\text { followed by POV-I, Proplis, } \\
\text { MCJ, and } \mathrm{Ca}(\mathrm{OH}) 2\end{array}$ \\
\hline 8 & $\begin{array}{l}\text { Nagesh Bolla } \\
\text { et al. }\end{array}$ & 2012 & India & $\begin{array}{l}\text { Odontoposte, } \\
\text { CHX, Propolis }\end{array}$ & $\begin{array}{l}\text { No } \\
\text { medicament- } \\
\text { Negativce } \\
\text { control }\end{array}$ & $\begin{array}{c}\text { Odontopaste has better } \\
\text { antibacterial efficacy against } \\
\text { Enterococcus faecalis followed } \\
\text { by Chlorhexidine, Propolis } \\
\text { shows partial antifungal } \\
\text { efficacy against } \\
\text { Candida albicans. }\end{array}$ \\
\hline
\end{tabular}


Table 1. Cont.

\begin{tabular}{|c|c|c|c|c|c|c|}
\hline $\begin{array}{l}\text { Study } \\
\text { Number }\end{array}$ & Authors & Year & Country & Test Group & Control Group & Outcome \\
\hline \multicolumn{7}{|c|}{ Group 2. Optical density as outcome measure } \\
\hline 9 & $\begin{array}{c}\text { Shruti Saha } \\
\text { et al. }\end{array}$ & 2015 & India & $\begin{array}{l}\text { Propolis, } \\
\mathrm{CHX}+\text { metronidazole, } \\
\text { Curcuma longa } \\
\mathrm{CaOH},\end{array}$ & Saline & $\begin{array}{l}\text { Propolis showed the least } \\
\text { value of optical density ( } 0.33 \\
\pm 0.62) \text { indicating it as the best } \\
\text { antibacterial medicament } \\
\text { while CHX and metronidazole } \\
\text { combination and Curcuma } \\
\text { Longa also showed better } \\
\text { efficiency than calcium } \\
\text { hydroxide. }\end{array}$ \\
\hline \multicolumn{7}{|c|}{ Group 3. Culture medium turbidity as outcome measure } \\
\hline 10 & $\begin{array}{c}\text { Juliana Ferreira } \\
\text { Piovesani }\end{array}$ & 2012 & Brazil & $\begin{array}{l}\text { Copaiba oil, } \\
\text { Propolis } \\
\text { extracts, } \mathrm{CHX}, \\
\text { propylene } \\
\text { glycol, } \mathrm{CaOH}\end{array}$ & $\begin{array}{l}\text { +ve control } \\
\text { group = } \\
\text { propylene } \\
\text { glycol } \\
\text { - ve control } \\
\text { group = No } \\
\text { inoculation }\end{array}$ & $\begin{array}{l}\text { None of these medicaments } \\
\text { proved to be considerably } \\
\text { bactericidal. }\end{array}$ \\
\hline
\end{tabular}

Table 2. Outcomes of studies included in systematic review.

\begin{tabular}{|c|c|c|c|c|c|c|c|c|c|c|}
\hline $\begin{array}{l}\text { Article } \\
\text { Number }\end{array}$ & $\begin{array}{l}\text { Total Number } \\
\text { of Samples }\end{array}$ & $\begin{array}{c}\text { Test } \\
\text { Group }\end{array}$ & $\begin{array}{l}\text { Control } \\
\text { Group }\end{array}$ & $\begin{array}{l}\text { Permanent } \\
\text { Teeth Studied }\end{array}$ & Medicaments & $\begin{array}{l}\text { Medicament } \\
\text { Duration }\end{array}$ & $\begin{array}{l}\text { Inoculation } \\
\text { Period }\end{array}$ & $\begin{array}{l}\text { Outcome } \\
\text { Measure }\end{array}$ & $\begin{array}{l}\text { Outcome } \\
\text { Evaluation } \\
\text { Method }\end{array}$ & CFU Count Difference \\
\hline \multicolumn{11}{|c|}{ Group 1. Studies performed on anterior/single rooted teeth } \\
\hline 1 & 50 & 40 & 10 & $\begin{array}{l}\text { Single rooted } \\
\text { teeth }\end{array}$ & Odontoposte, CHX, Propolis & $24-48 \mathrm{~h}$ & $24 \mathrm{~h}$ & $\begin{array}{l}\text { CFU count and } \\
\text { Zones of } \\
\text { inhibition }\end{array}$ & $\begin{array}{l}\text { Colonies } \\
\text { Counted }\end{array}$ & $\begin{array}{c}\text { Chlorhexidine } \\
1.60 \pm 0.52 \mathrm{Cfu} / \mathrm{mL} \\
\text { Propolis: } 9.10 \pm 0.74 \mathrm{Cfu} / \mathrm{mL} \\
\text { Mean Zone of inhibition } \\
\text { (in mm): } \\
24 \mathrm{~h}>\mathrm{CHX}=4.80 \\
\text { Propolis }=11.9 \\
48 \mathrm{~h}>\mathrm{CHX}=1.60 \\
\text { Propolis }=9.10\end{array}$ \\
\hline 2 & 120 & 90 & 30 & $\begin{array}{l}\text { Single rooted } \\
\text { teeth }\end{array}$ & $\mathrm{CHX}$, Propolis, $\mathrm{CaOH}$, saline & 14 days & 21 days & CFU count & $\begin{array}{l}\text { Colonies } \\
\text { counted }\end{array}$ & $\begin{array}{c}\text { Chlorhexidine }=0 \\
\text { Propolis }=0.86 \mathrm{Cfu} / \mathrm{mL}\end{array}$ \\
\hline 3 & 120 & 90 & 30 & Anterior teeth & $\mathrm{CHX}$, Propolis, $\mathrm{CaOH}$, Saline & $1,3,5$ days & 21 days & CFU count & $\begin{array}{l}\text { Digital colony } \\
\text { counter }\end{array}$ & $\begin{array}{c}\text { Chlorhexidine }=0 \\
\text { Propolis }=1.13 \mathrm{Cfu} / \mathrm{mL}\end{array}$ \\
\hline 4 & 90 & 60 & 30 & $\begin{array}{l}\text { Single rooted } \\
\text { teeth }\end{array}$ & $\begin{array}{l}\text { Triantibiotic, CHX, Propolis, } \\
\text { Aloe Vera }\end{array}$ & 7 days & 21 days & CFU count & $\begin{array}{l}\text { Colonies } \\
\text { counted and } \\
\text { recorded by } \\
\text { blinded } \\
\text { microbiologist }\end{array}$ & $\begin{array}{c}\text { Chlorhexidine }= \\
0.88 \pm 0.57 \mathrm{Cfu} / \mathrm{mL} \\
\text { Propolis }=2.93 \pm 2.88 \mathrm{Cfu} / \mathrm{mL}\end{array}$ \\
\hline 5 & 96 & 84 & 12 & $\begin{array}{l}\text { single-rooted } \\
\text { teeth }\end{array}$ & $\begin{array}{l}\text { Propolis, ginger extracts, } \\
\text { CHX, CaOH }\end{array}$ & 14 days & 21 days & CFU count & $\begin{array}{l}\text { Serial dilution } \\
\text { and plated } \\
\text { method }\end{array}$ & $\begin{array}{c}\text { Chlorhexidine }= \\
0.87 \pm 0.18 \mathrm{Cfu} / \mathrm{mL} \\
\text { Propolis }=0.98 \pm 0.03 \mathrm{Cfu} / \mathrm{mL}\end{array}$ \\
\hline 6 & 90 & 72 & 18 & $\begin{array}{l}\text { single-rooted } \\
\text { teeth }\end{array}$ & $\begin{array}{c}\text { Propolis, } \\
\text { CHX+metronidazole, } \\
\text { Curcuma longa } \\
\text { CaOH, }\end{array}$ & $\begin{array}{l}1,2 \text { and } \\
5 \text { days }\end{array}$ & 21 days & Optical Density & $\begin{array}{l}\text { Optical density } \\
\text { calculated } \\
\text { using } \\
\text { colorimeter }\end{array}$ & $\begin{array}{c}\text { Value of Optical Density: } \\
\text { Propolis: } 0.33 \pm 0.02 \\
\text { CHX + metronidazole: } \\
0.34 \pm 0.03\end{array}$ \\
\hline 7 & 96 & 64 & 32 & $\begin{array}{l}\text { Extracted } \\
\text { single-rooted } \\
\text { human teeth }\end{array}$ & $2 \% \mathrm{CHX}$, Propolis, $\mathrm{CaOH}$ & $\begin{array}{l}1 \text { day/ } \\
7 \text { days }\end{array}$ & 14 days & CFU count & $\begin{array}{l}\text { Colonies } \\
\text { counted }\end{array}$ & $\begin{array}{c}\text { Percent Reduction in CFU: } \\
\text { CHX: } 10 \% \\
\text { Propolis: } 71 \%\end{array}$ \\
\hline 8 & 50 & 40 & 10 & $\begin{array}{l}\text { Single rooted } \\
\text { teeth }\end{array}$ & $\begin{array}{l}\text { Copaiba oil, Propolis } \\
\text { extracts, } \mathrm{CHX} \text {, propylene } \\
\text { glycol, } \mathrm{CaOH}\end{array}$ & 7 days & $48 \mathrm{~h}$ & $\begin{array}{l}\text { Culture } \\
\text { medium } \\
\text { turbidity }\end{array}$ & $\begin{array}{l}\text { Unique } \\
\text { calibrated } \\
\text { examiner } \\
\text { analyzed } \\
\text { culture medium } \\
\text { ranking. }\end{array}$ & $\begin{array}{l}\text { Culture medium turbidity } \\
\text { Chlorhexidine }=+++ \\
\text { Propolis }=+++\end{array}$ \\
\hline \multicolumn{11}{|c|}{ Group 2. Studies performed on mandibular premolar teeth } \\
\hline 9 & 210 & 180 & 30 & $\begin{array}{l}\text { Mandibular } \\
\text { first premolar }\end{array}$ & $\begin{array}{l}\text { Propolis, Chlorhexidine, } \\
\text { Honey gel, Calcium } \\
\text { hydroxide, Curcuma longa } \\
\text { gel, Aloe vera gel, saline }\end{array}$ & $1,3,5$ days & 21 days & CFU count & $\begin{array}{l}\text { Colonies } \\
\text { counted }\end{array}$ & $\begin{array}{c}\text { Chlorhexidine }= \\
0.10 \pm 0.31 \mathrm{Cfu} / \mathrm{mL} \\
\text { Propoli } \mathrm{s}=2.80 \pm 0.63 \mathrm{Cfu} / \mathrm{mL}\end{array}$ \\
\hline 10 & 180 & 150 & 30 & $\begin{array}{l}\text { single-rooted } \\
\text { human } \\
\text { mandibular } \\
\text { premolar teeth }\end{array}$ & $\begin{array}{l}\text { Propolis, MCJ(morinda } \\
\text { citrifolia juice), } \mathrm{CaOH}, \\
\text { Povidone Iodine, } \mathrm{CHX}\end{array}$ & $\begin{array}{l}1,3 \text { and } \\
5 \text { days }\end{array}$ & 21 days & CFU count & $\begin{array}{l}\text { Colonies } \\
\text { Counted }\end{array}$ & $\begin{array}{c}\text { Chlorhexidine }=0 \pm 0 \\
\text { Propolis }=2.1 \pm 0.56 \mathrm{Cfu} / \mathrm{mL}\end{array}$ \\
\hline
\end{tabular}




\subsection{Quality Assessment of the Studies}

The quality assessment of the studies was performed through the revised Cochrane Risk of Bias tool [RoB 2.0, Cochrane Methods, London, UK] (Higgins et al., 2016). A slight modification of this tool was made in order to include content used in the methodology of all included in-vitro studies. The quality of all studies was thoroughly evaluated based on multiple factors including, tooth specimen preparation protocol, smear layer removal protocol prior to E. faecalis inoculation, specimen sterilization before inoculation, growth of E. faecalis verified, purity of the culture checked, randomly divided samples, medicament placement protocol, and confirmation of bacterial identity after medicament removal (Table 3).

Table 3. Risk of bias assessment for included studies, based on standardization of reported factors. These included specimen preparation, smear layer removal, specimen sterilization, verification of E. faecalis growth, purity of the culture, randomized sampling, medicament placement protocol, and confirmation of bacterial identity after medicament removal.

\begin{tabular}{|c|c|c|c|c|c|c|c|c|c|c|c|c|}
\hline $\begin{array}{l}\text { S. } \\
\text { No }\end{array}$ & Authors & Year & Country & $\begin{array}{c}\text { Tooth } \\
\text { Preparation } \\
\text { Protocol }\end{array}$ & $\begin{array}{c}\text { Smear Layer } \\
\text { Removal }\end{array}$ & $\begin{array}{c}\text { Specimen } \\
\text { Sterilization } \\
\text { before Inoculation }\end{array}$ & $\begin{array}{l}\text { Growth of } \\
\text { E. faecalis } \\
\text { Verified }\end{array}$ & $\begin{array}{c}\text { Purity of } \\
\text { Culture }\end{array}$ & Randomization & $\begin{array}{c}\text { Medicament } \\
\text { Placement } \\
\text { Protocol }\end{array}$ & $\begin{array}{l}\text { Confirmation } \\
\text { of Bacterial } \\
\text { Identity }\end{array}$ & $\begin{array}{c}\text { Overall } \\
\text { Score } \\
(8)\end{array}$ \\
\hline 1 & $\begin{array}{l}\text { Agrima Vasudeva } \\
\text { et al. }\end{array}$ & 2017 & India & Yes & Yes & Yes & Yes & Yes & No & Yes & No & 6 \\
\hline 2 & $\begin{array}{l}\text { Jeison B. Carbajal } \\
\text { Mejía }\end{array}$ & 2014 & Peru & Yes & Yes & Yes & Yes & Yes & No & Yes & No & 6 \\
\hline 3 & Sonam Bhandari et al. & 2014 & India & Yes & Yes & Yes & Yes & Yes & No & Yes & No & 6 \\
\hline 4 & Leila Bazvand et al. & 2014 & Iran & Yes & Yes & Yes & Yes & No & Yes & Yes & Yes & 7 \\
\hline 5 & Maekawa et al. & 2013 & Brazil & No & Yes & Yes & Yes & No & Yes & Yes & No & 5 \\
\hline 6 & Shruti Saha et al. & 2015 & India & Yes & Yes & Yes & Yes & No & No & Yes & No & 5 \\
\hline 7 & Guven Kayaoglu et. al & 2011 & Turkey & Yes & Yes & Yes & Yes & Yes & Yes & Yes & No & 7 \\
\hline 8 & D. Kandaswamy et al. & 2010 & India & Yes & Yes & Yes & Yes & Yes & No & Yes & No & 6 \\
\hline 9 & Nagesh et al. & 2011 & India & No & Yes & No & No & No & No & Yes & No & 2 \\
\hline 10 & Juliana et al. & 2012 & Brazil & No & No & Yes & Yes & No & Yes & No & No & 3 \\
\hline
\end{tabular}

\subsection{Meta-Analysis}

Heterogeneity was calculated for colony forming units (CFU) of E. faecalis using the Chi-square test and $\mathrm{I}^{2}$ statistics. For meta-analyses, if the $\mathrm{I}^{2}$ was higher than $50 \%$, a randomeffects model was used; otherwise, a fixed-effects model for $\mathrm{I}^{2} \leq 50 \%$ was applied. A $P$-value of $<0.05$ was set for significant heterogeneity. Forest plots were computed reporting standard mean difference (SMD) of outcomes and 95\% confidence intervals (CI).

\section{Results}

\subsection{Study Selection}

The PRISMA flow chart for the selection of studies is shown in Figure 1. A total of 63 studies were retrieved after the initial search from four databases. No additional record was found by manual search. 38 studies were selected after duplicate studies removal. Selected articles were screened thoroughly, and 28 were excluded based on predetermined criteria. The remaining 10 studies [15-24] were included in qualitative analysis, and meta-analysis was performed on eight articles only [15,18-24].

\subsection{General Characteristics of the Studies Included}

All studies included in the review were published between July 2000 and July 2020. Test medicaments include chlorhexidine and Propolis specifically, along with other medicaments, e.g., honey gel, calcium hydroxide, Curcuma longa, aloe vera gel, tri-antibiotic paste, glycolic ginger extracts, calcium hydroxide plus metronidazole, etc. Control groups used saline in all studies, although propylene glycol [18] and ethanol [16] were used as controls in two studies. Most of the studies used CFU (Colony Forming Units) count as an outcome measure, however, the outcome in three studies was assessed by optical density [23], culture medium turbidity [18], and bacterial zones of inhibition [17].

\subsection{Main Outcomes of the Study}

Five out of ten included studies concluded that chlorhexidine showed better antibacterial properties than Propolis against Enterococcus faecalis $[15-17,21,24]$. In three out of ten studies included in the review, Propolis was equally effective against $E$. faecalis as an 
intracanal medicament $[19,20,22]$. However, only one study presented contrary results [23]. Finally, one study conducted by Piovesani et al. [18] assessed the bactericidal activity of multiple medicaments and showed that none of the medicaments was considerably bactericidal.

\subsection{Quality Assessment of the Studies Included}

The risk of bias was assessed using the Cochrane Risk of Bias Tool [25]. Studies were categorized as high risk (Score 0-3), moderate risk (Score 4-6), and low risk (Score 7-8). The risk of bias assessment was performed on the basis of tooth specimen preparation protocol (by Haapasalo and Orstavik Model) [26], smear layer removal protocol prior to E. faecalis inoculation, specimen sterilization before inoculation, verification of growth of E. faecalis, purity of culture assessed, random division of samples, medicament placement protocol, and confirmation of bacterial identity after medicament removal. Only two of the studies included had a high risk of bias [Score 0-3] [17,18]. Six out of ten studies had a moderate risk of bias [Score 4-6] [15,19,21-24], however, two studies showed a low risk of bias [Score 7-8] [16,20].

\subsection{Meta-Analysis}

There was significant heterogeneity $\left(\mathrm{Chi}^{2}=357.26, P<0.0001, \mathrm{I}^{2}=98.04 \%\right)$ for the mean CFU count of E. Faecalis bacteria, therefore, a random-effect model was utilized between the groups. A total of eight studies were included for the meta-analyses [15,18-24]. The overall mean difference for E. Faecalis CFU between antibacterial effect of Propolis and CHX (control) was statistically significant $(\mathrm{SMD}=3.20[1.70,4.69] \mathrm{Z}=4.20 ; p<0.001)$. Although Propolis showed a significant reduction of E. Faecalis as compared to no treatment, CHX exhibited a significantly higher antimicrobial effect on E. Faecalis in comparison to Propolis $(p<0.001)$ (Figure 2).

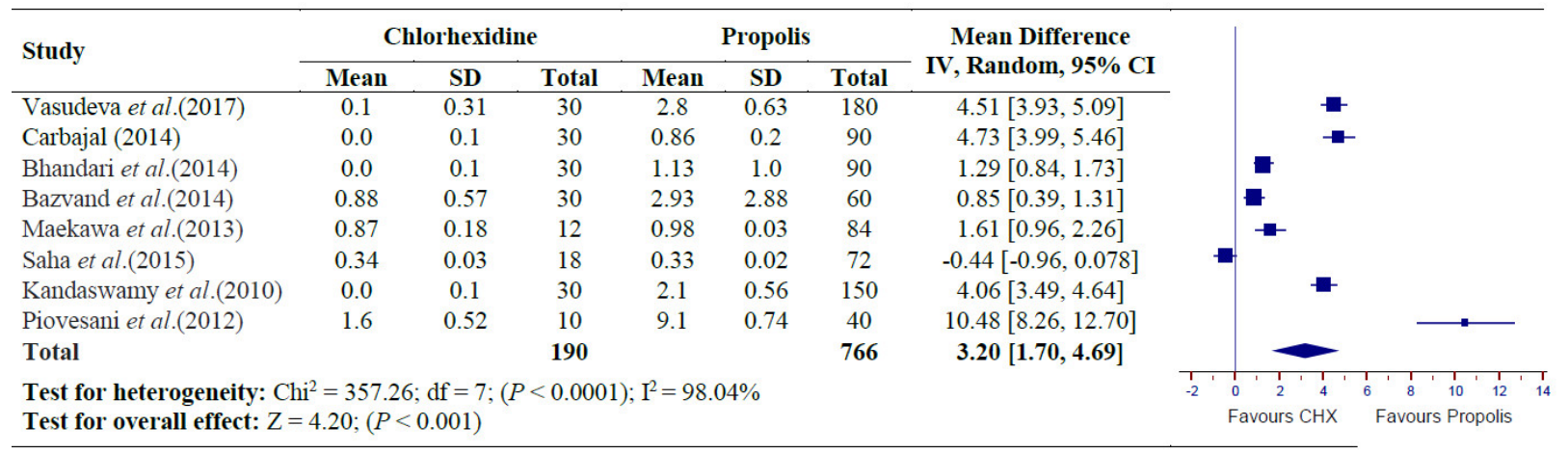

Figure 2. Forest plot showing standard mean difference between Propolis and CHX (control group) treatment in the reduction of E. Faecalis Colony forming units.

\section{Discussion}

The present study was based on the hypothesis that Propolis exhibits comparable antimicrobial efficacy in comparison to CHX against E. faecalis. The outcomes of the present systematic review and meta-analysis showed that the antibacterial efficacy of Propolis as an intracanal medicament against $E$. faecalis was not comparable or superior to chlorhexidine. Therefore, based on these observations, the hypothesis was rejected.

Since absolute disinfection of the root canal system is not achievable with instrumentation unaided by intracanal medicament. The use of medicaments is of particular importance to remove remaining microbes and create an environment favorable for periradicular tissue repair. In endodontic treatment, chlorhexidine, iodine potassium iodide, and their combinations with calcium hydroxide have been found effective in reducing the numbers of $E$. faecalis in the root canal system. However, none of these are considered to ensure complete eradication of E. faecalis [20]. E. faecalis is a gram-positive, facultative 
anaerobe that is present in $22-77 \%$ of cases of endodontic failure and is recovered from previously root canal-treated teeth with peri-radicular infection $[27,28]$. It can survive as a single organism or as a major part of the endodontic flora even in ecologically demanding conditions [29]. It can penetrate dentinal tubules and has the remarkable ability to adapt to lethal changes. The capability of the microbe to invade dentinal tubules and adhere to collagen in the presence of human serum can be considered as a virulence factor responsible for its presence in failed endodontically treated teeth $[17,30,31]$. E. faecalis forms biofilms, which even prolongs its survival by making it resistant to phagocytosis, antibodies, and antimicrobial agents.

In the present systematic review, five out of ten included studies [15-17,21,24] concluded that chlorhexidine was more effective than Propolis against E. faecalis as an intracanal medicament. Chlorhexidine is a bis-biguanide and effective intracanal medicament in endodontic, with substantivity. It is active against gram-positive as well as gram-negative organisms, particularly E. faecalis [24]. Vasudeva et al. [24] evaluated the antibacterial efficacy of Propolis and 2\% CHX along with other medicaments, showing maximum microbial inhibition of up to 200-400 micrometers depth, while Propolis exhibited the second highest antibacterial efficacy against E. faecalis among all medicaments. Other studies also reported similar results and mentioned chlorhexidine as a more effective intracanal medicament against E. faecalis [15,16,21]. Interestingly, Arsalan et al. [32] assessed the minimum inhibitory concentrations of $\mathrm{CHX}$ and Propolis along with other irrigants, concluding that Propolis was more effective in lower concentrations $(\mathrm{MBC}=0.150 \mathrm{mg} / \mathrm{mL}$ compared to $0.512 \mathrm{mg} / \mathrm{mL}$ of $\mathrm{CHX}$ ) against Candida albicans, while CHX was more effective in lower concentrations against E. faecalis $(0.256 \mathrm{mg} / \mathrm{mL}$ compared to $0.6 \mathrm{mg} / \mathrm{mL}$ of Propolis). Although the study was not performed on extracted teeth, it reported that chlorhexidine is bactericidal to E. faecalis in lower concentrations as compared to Propolis. However, since $E$. faecalis entraps in dentinal tubules and the study did not assess bacterial inhibition in extracted teeth, possibly contrasting outcomes could have resulted if extracted teeth were used.

In the present study, three studies also concluded that the antibacterial efficacy of Propolis is comparable to CHX against E. faecalis [19,20,22]. Propolis has been used as an antibacterial agent in traditional medications for a very long time. Its antibacterial efficacy is attributed to its concentration and flavonoid contents. Kayaoglu et al. [16] compared two ethanolic extracts of Propolis, ART (Artvin, northeast Turkey) and TM (a mixed sample containing Propolis collected from hives from four different areas in Tekirda). They showed comparable antibacterial outcomes; however, TM samples contained 1.7 times more flavonoids. In another study, it was observed that flavonoid-rich Propolis extracts also inhibit bacterial growth at lower concentrations [33]. Therefore, the authors hypothesize that the difference in flavonoid contents may be the reason why Propolis exhibited inferior antibacterial properties than chlorhexidine in other includes [15-17,21,24].

On the contrary, one study conducted by Saha et al. [23] concluded that Propolis was a better intracanal medicament than chlorhexidine against $E$. faecalis. These findings among the included studies may be attributed to the different methodological techniques utilized for assessing microbial inhibition. The different techniques used included optical density and CFU counts. Another study conducted by Piovesani et al. [18] employed culture medium turbidity, concluding that none of the medicaments assessed proved to be considerably bactericidal. A number of studies assessed the role of Propolis as an intracanal medicament or irrigant due to its remarkable antibacterial properties [16,24]. Propolis possesses remarkable antibacterial and anti-inflammatory properties due to its flavonoids contents (quercetin, galangin, pinocembrin) and caffeic acid [24]. Numerous studies observed good antimicrobial activity of Propolis against E. faecalis, suggesting its use as an intracanal medicament in lieu of conventional medicaments [15,29]. All the studies included in the review confirm the bactericidal properties of Propolis against E. faecalis and other microbes of endodontic origin. 


\section{Limitations}

Although the findings suggest superior antimicrobial activity of $\mathrm{CHX}$, in comparison to Propolis in inhibiting E. faecalis, it is pertinent to mention that the studies included were in-vitro, with an inherent limitation when simulating in-vivo environment; therefore, results should be interpreted cautiously. In addition, the quality assessment of the included studies reflected a low to moderate body of available evidence on which conclusions were based. Therefore, further in-vivo randomized controlled trials investigating the efficacy of Propolis as a root canal medicament against E. faecalis are recommended.

\section{Conclusions}

As an intracanal medicament, Propolis displayed bactericidal ability against E. faecalis. However, chlorhexidine showed significantly higher antibacterial efficacy towards E. faecalis than Propolis. Further randomized controlled trials are recommended to validate the bactericidal potential of Propolis intracanal medicament against E. faecalis.

Author Contributions: Conceptualization, M.A.A.; methodology, F.V.; software, T.A.; validation, K.H.A. and R.J.; formal analysis, M.A.A.; investigation, M.A.A., R.J.; resources, M.F.A.; data curation, T.G.; writing—original draft preparation, M.A.A., R.J. and T.G.; writing—review and editing, F.V. and R.J.; visualization, M.A.A. and K.H.A.; supervision and project administration, T.A. and M.F.A.; funding acquisition, K.H.A. All authors have read and agreed to the published version of the manuscript.

Funding: No funding was received.

Institutional Review Board Statement: Not applicable.

Informed Consent Statement: Not applicable.

Data Availability Statement: Study data is available from the corresponding author on request.

Acknowledgments: The authors are grateful to the Deanship of Scientific Research, King Faisal University, Al-Ahsa for facilitating this project.

Conflicts of Interest: The authors declare no conflict of interest.

Registration: PROSPERO (International prospective register of systematic reviews) CRD42020201052.

\section{References}

1. Gajan, E.B.; Aghazadeh, M.; Abashov, R.; Milani, A.S.; Moosavi, Z. Microbial flora of root canals of pulpally-infected teeth: Enterococcus faecalis a prevalent species. J. Dent. Res. Dent. Clin. Dent. Prospects 2009, 3, 24.

2. Wang, Q.-Q.; Zhang, C.-F.; Chu, C.-H.; Zhu, X.-F. Prevalence of Enterococcus faecalis in saliva and filled root canals of teeth associated with apical periodontitis. Int. J. Oral Sci. 2012, 4, 19-23. [CrossRef] [PubMed]

3. Saber, S.E.-D.M.; El-Hady, S.A. Development of an intracanal mature Enterococcus faecalis biofilm and its susceptibility to some antimicrobial intracanal medications; an in vitro study. Eur. J. Dent. 2012, 6, 43.

4. Ahmed, M.A.; Sharif, Z.; Aafreen, A. Comparison of removal potency of different intracanal medicaments. Pak. Oral Dent. J. 2017, 37, 483-487.

5. Madarati, A.A.; Zafar, M.S.; Sammani, A.M.N.; Mandorah, A.O.; Bani-Younes, H.A. Preference and usage of intracanal medications during endodontic treatment. Saudi Med. J. 2017, 38, 755. [CrossRef] [PubMed]

6. McDonnell, G.; Russell, A.D. Antiseptics and disinfectants: Activity, action, and resistance. Clin. Microbiol. Rev. 1999, 12, 147-179. [CrossRef] [PubMed]

7. De Lucena, J.; Decker, E.M.; Walter, C.; Boeira, L.S.; Löst, C.; Weiger, R. Antimicrobial effectiveness of intracanal medicaments on Enterococcus faecalis: Chlorhexidine versus octenidine. Int. Endod. J. 2013, 46, 53-61. [CrossRef] [PubMed]

8. Savitha, A.; SriRekha, A.; Vijay, R.; Champa, C.; Jaykumar, T. An in vivo comparative evaluation of antimicrobial efficacy of chitosan, chlorhexidine gluconate gel and their combination as an intracanal medicament against Enterococcus faecalis in failed endodontic cases using real time polymerase chain reaction (qPCR). Saudi Dent. J. 2019, 31, 360-366. [CrossRef] [PubMed]

9. Sinha, D.J.; Sinha, A.A. Natural medicaments in dentistry. Ayu 2014, 35, 113. [CrossRef]

10. Pietta, P.G.; Gardana, C.; Pietta, A.M. Analytical methods for quality control of Propolis. Fitoterapia 2002, 73, S7-S20. [CrossRef]

11. Abbasi, A.J.; Mohammadi, F.; Bayat, M.; Gema, S.M.; Ghadirian, H.; Seifi, H.; Bayat, H.; Bahrami, N. Applications of Propolis in dentistry: A review. Ethiop. J. Health Sci. 2018, 28, 505-512.

12. Victorino, F.R.; Bramante, C.M.; Watanabe, E.; Ito, I.Y.; Franco, S.L.; Hidalgo, M.M. Antibacterial activity of Propolis-based toothpastes for endodontic treatment. Braz. J. Pharm. Sci. 2009, 45, 795-800. [CrossRef] 
13. Awawdeh, L.; AL-Beitawi, M.; Hammad, M. Effectiveness of Propolis and calcium hydroxide as a short-term intracanal medicament against Enterococcus faecalis: A laboratory study. Aust. Endod. J. 2009, 35, 52-58. [CrossRef] [PubMed]

14. Madhubala, M.M.; Srinivasan, N.; Ahamed, S. Comparative evaluation of Propolis and triantibiotic mixture as an intracanal medicament against Enterococcus faecalis. J. Endod. 2011, 37, 1287-1289. [CrossRef]

15. Kandaswamy, D.; Venkateshbabu, N.; Gogulnath, D.; Kindo, A.J. Dentinal tubule disinfection with 2\% chlorhexidine gel, Propolis, morinda citrifolia juice, 2\% povidone iodine, and calcium hydroxide. Int. Endod. J. 2010, 43, 419-423. [CrossRef] [PubMed]

16. Kayaoglu, G.; Ömürlü, H.; Akca, G.; Gürel, M.; Gençay, Ö.; Sorkun, K.; Salih, B. Antibacterial activity of Propolis versus conventional endodontic disinfectants against Enterococcus faecalis in infected dentinal tubules. J. Endod. 2011, 37, 376-381. [CrossRef] [PubMed]

17. Bolla, N.; Kavuri, S.R.; Tanniru, H.I.; Vemuri, S.; Shenoy, A. Comparative evaluation of antimicrobial efficacy of odontopaste, chlorhexidine and Propolis as root canal medicaments against Enterococcus faecalis and Candida albicans. J. Int. Dent. Med. Res. 2012, 5, 14 .

18. Piovesani, J.F.; Semenoff-Segundo, A.; Pedro, F.; Borges, A.H.; Neves, A.N.P.; Mamede Neto, L.; Semenoff, T. Antibacterial capacity of different intracanal medications on Enterococcus faecalis. Dent. Press Endod. 2012, 2, 53-58.

19. Maekawa, L.E.; Valera, M.C.; de Oliveira, L.D.; Carvalho, C.A.T.; Camargo, C.H.R.; Jorge, A.O.C. Effect of Zingiber officinale and Propolis on microorganisms and endotoxins in root canals. J. Appl. Oral Sci. 2013, 21, 25-31. [CrossRef]

20. Bazvand, L.; Aminozarbian, M.G.; Farhad, A.; Noormohammadi, H.; Hasheminia, S.M.; Mobasherizadeh, S. Antibacterial effect of triantibiotic mixture, chlorhexidine gel, and two natural materials Propolis and Aloe vera against Enterococcus faecalis: An ex vivo study. Dent. Res. J. 2014, 11, 469.

21. Bhandari, S.; Ashwini, T.S.; Patil, C.R. An in vitro evaluation of antimicrobial efficacy of $2 \%$ chlorhexidine gel, Propolis and calcium hydroxide against Enterococcus faecalis in human root dentin. J. Clin. Diagn. Res. JCDR 2014, 8, ZC60. [CrossRef]

22. Carbajal Mejía, J.B. Antimicrobial effects of calcium hydroxide, chlorhexidine, and Propolis on Enterococcus faecalis and Candida albicans. J. Investig. Clin. Dent. 2014, 5, 194-200. [CrossRef]

23. Saha, S.; Nair, R.; Asrani, H. Comparative Evaluation of Propolis, Metronidazole with Chlorhexidine, Calcium Hydroxide and Curcuma Longa Extract as Intracanal Medicament Against E. faecalis-An Invitro Study. J. Clin. Diagn. Res. JCDR 2015, 9, ZC19.

24. Vasudeva, A.; Sinha, D.J.; Tyagi, S.P.; Singh, N.N.; Garg, P.; Upadhyay, D. Disinfection of dentinal tubules with $2 \%$ Chlorhexidine gel, Calcium hydroxide and herbal intracanal medicaments against Enterococcus faecalis: An in-vitro study. Singap. Dent. J. 2017, 38, 39-44. [CrossRef] [PubMed]

25. Higgins, J.P.T.; Sterne, J.A.C.; Savovic, J.; Page, M.J.; Hróbjartsson, A.; Boutron, I.; Reeves, B.; Eldridge, S. A revised tool for assessing risk of bias in randomized trials. Cochrane Database Syst. Rev. 2016, 10, $29-31$.

26. Saleh, I.M.; Ruyter, I.E.; Haapasalo, M.; Ørstavik, D. Survival of Enterococcus faecalis in infected dentinal tubules after root canal filling with different root canal sealers in vitro. Int. Endod. J. 2004, 37, 193-198. [CrossRef] [PubMed]

27. Stuart, C.H.; Schwartz, S.A.; Beeson, T.J.; Owatz, C.B. Enterococcus faecalis: Its role in root canal treatment failure and current concepts in retreatment. J. Endod. 2006, 32, 93-98. [CrossRef] [PubMed]

28. Dall, A.Q.; Jouhar, R.; Khoso, N.A. Comparison of Inter-appointment Pain between Ledermix and no intracanal medicament in acute apical periodontitis. J. Liaquat. Univ. Med. Health Sci. 2011, 10, 106-111.

29. Oncag, O.; Cogulu, D.; Uzel, A.; Sorkun, K. Efficacy of Propolis as an intracanal medicament against Enterococcus faecalis. Gen. Dent. 2006, 54, 319-322.

30. Ahmed, M.A.; Dall, A.Q.; Khoso, N.A.; Jouhar, R. Comparison of postoperative pain after Protaper rotary and manual step-back root canal preparation techniques in single visit endodontics. JPDA 2012, 21, 104.

31. Ahmed, N.; Jouhar, R.; Sheikh, I.; Dawani, N. Comparison of Endodontic Treatment Outcome with Protaper and K3 Rotary Systems Comparison of Endodontic Treatment Outcome with Protaper and K3 Rotary Systems. J. Pak. Dent. Assoc. 2013, 22, 206-211.

32. Arslan, S.; Ozbilge, H.; Kaya, E.G.; Er, O. In vitro antimicrobial activity of Propolis, BioPure MTAD, sodium hypochlorite, and chlorhexidine on Enterococcus faecalis and Candida albicans. Saudi Med. J. 2011, 32, 479-483. [PubMed]

33. Salomão, K.; Dantas, A.P.; Borba, C.M.; Campos, L.C.; Machado, D.G.; Aquino Neto, F.R.; De Castro, S.L. Chemical composition and microbicidal activity of extracts from Brazilian and Bulgarian Propolis. Lett. Appl. Microbiol. 2004, 38, 87-92. [CrossRef] [PubMed] 